\title{
コンクリートの引張強度に及ぼす曲げ変形の影響に関する一考察 EFFECT OF BENDING DEFORMATION UPON TENSILE STRENGTH OF CONCRETE
}

\author{
篠 原 保 二*, 安 部 武 雄*, 古村福次郎** \\ Yasuji SHINOHARA, Takeo ABE and Fukujiro FURUMURA
}

\begin{abstract}
In order to investigate how the bending moment generated in concrete during the tensile tests would affect its tensile strength, the direct tensile tests were performed on cylindrical specimens with and without spherical bearings. Six linearly varying transducers were installed at equal spaces in the circumference of a cylinder to estimate the bending deformation. The results showed that the bending deformation was also produced in a specimen due to the heterogeneity even if spherical bearings were used. The specimens without spherical bearings showed the tensile strength lower by 30 to $35 \%$ than those with spherical bearings because of the larger bending deformation. The effect of the bending deformation upon the tensile strength was studied based on linear elastic fracture mechanics.
\end{abstract}

Keywords: concrete, direct tensile test, tensile strength, bending deformation,
linear elastic fracture mechanics
コンクリート, 直接引張試験, 引張強度, 曲げ変形, 線形破壊力学

\section{1.はじめに}

直接引張試験は、コンクリートの引張軟化特性を決定 する最も直接的な試験法である。しかしながら、直接引 張試験によって引張軟化特性を決定するためには、最大 荷重後も安定した荷重一変形関係を測定することが必要 である。そのような测定を行うために、Hughes と Chapman (1) およびEvans と Marathe(2) は、鋼製の岡性ブ ロックまたは鋼棒によって試験機の剛性を高めて、コン クリートの引張試験を行っている。ただし、最大荷重を 越え、荷重が減少していくと、軟化領域にひずみが集中 し、ダメージを受けていない部分のひずみは弾性的に回 復するため、試験体のひずみ分布は不均一となるが、そ の測定は行っていない。GopalaratnamとShah(3)は、コン クリートの引張軟化応答を特徴づけるために、試験体の 異なる位置におけるひずみ、異なるグージ長に対する伸 びおよびクラック幅の測定をサーボコントロール試験機 を用いて行っている。ただし、試験体のつかみ治具の制
約から、試験体厚さが $19 \mathrm{~mm}$ と小さい。Guo と Zhang(4)は 断面が70x70mmのコンクリート試験体を用いて、直接引 張試験を行っている。試験機の㓮性を 4 本の銅棒（直径 $20 \mathrm{~mm}$ ）によって高め、試験体に貼り付けた数ケ所のひず みゲージから、最大荷重以後、試験体内のひずみ分布が 不均一になることを観測している。また、コンクリート 特有の不均質さのため、試験体にクラックが入る前から 偏心が存在し、クラック後、さらにその偏心は大きくな り、実験結果に影響を及ぼすであろうと指摘している。 この偏心の影響を抑えるために、Reinhardt(5)は試験体の 回転を拘束するガイディングシステムを取り付けたサー ボコントロール試験機を用いて、引張試験を行っている。 このガイディングシステムはベースプレートに 4 本の剛 な支柱を取り付け、それらをアクチュエータに接続され ている上の圧盤に取り付けられたローラーベアリングの 中に正確に組み入れた装置である。ただし、ガイド装置 の摩擦力は無視している。この装置を用いても不均一な

Assoc. Prof., The Research Laboratory of Engineering Materials, Tokyo Institute of Technology, Dr. Eng.

Prof., The Research Laboratory of Engineering Materials, Tokyo Institute of Technology, Dr. Eng.
} 
弾性変形による試験体の小さな曲げは取り除くことがで きなかったと報告されている(6)。以上の試験はいずれも 試験体に球座を取り付けずに行ったものであり、曲げ変 形が試験結果に影響を与えたと考えられる。

本研究では、コンクリートの直接引張試験結果が大き く変動する要因として曲げ変形の影響を取り上げ、円周 ノッチを有するシリンダー試験体を用いて、球座を取り 付けた場合と取り外した場合の直接引張試験を行い、そ の試験結果に及ぼす曲げ変形の影響を線形破壊力学に基 づいて考察することを目的とする。

\section{2. クラックを有する部材の変形}

円周ノッチを有するシリンダー試験体のように、一般 にクラックを有する部材の変形を線形破壊力学に基づい て計算する方法について述べる(7)。

与えられた境界条件のもとでクラック面積が 0 から A まで成長して、荷重が $P_{1}, P_{2}, \cdots \cdots P_{n}$ なる最終状態に達し たとき、この状態でのひずみエネルギーや恋位は、弾性 体の場合、途中の経路に依存しないから、初めから最終 状態と同じ一定荷重が加わっている条件のもとでクラッ クが進展して、Aに達した場合のひずみエネルギーや変 位に等しいはずである。そこで、最終状態の荷重が加 わった状態で $\mathrm{A}=0$ の場合のひずみエネルギーを 重 $P_{i}$ の作用点の $P_{i}$ 方向の変位を $u_{i 0}$ と書き、クラックの 存在による増加分をそれぞれ $\Delta \bar{W}, \Delta u_{i}$ と書く。すなわ ち、全ひずみエネルギー $\bar{W}$ と全変位 $u_{i}$ は、

$$
\begin{gathered}
\bar{W}=\bar{W}_{0}+\Delta \bar{W} \\
u_{i}=u_{i 0}+\Delta u_{i}
\end{gathered}
$$

である。ただし、これらの増分は、同一の外力のもとに おいて比較したクラックの有無による差である。

次に、クラックによるひずみエネルギーの増加分を求 めるために、Griffith(8)の手法を用いる。すなわち、線形 弾性体の場合、クラックが単位面積だけ增加する際に解 放されるポテンシャルエネルギー（対象としているカ学 系全体のエネルギーを川とする。）G を、エネルギ一解 放率と呼び、これは、

$$
G=-\lim _{\delta A \rightarrow 0} \frac{\delta \prod}{\delta A}=-\frac{\partial \prod}{\partial A}
$$

で与えられる。特に、荷重が一定の場合は、ポテンシャ ルエネルギーの減少はひずみエネルギーの増加に等しい $(-\delta \Pi=\delta \bar{W})(7)$ ので、ひずみエネルギーを使って、

$$
G=\frac{\partial \bar{W}(P, A)}{\partial A}
$$

と書ける。したがって、(3)式を積分すれば、

$$
\bar{W}(P, A)=\bar{W}_{0}+\int_{0}^{A} G d A
$$

となる。荷重一定の条件下でのひずみエネルギーの増分 $\Delta \bar{W}$ は、(4)式の右辺第 2 項である。

クラックが存在あるいは進展することにより、このク ラックを含む部材の変位は同一荷重下で増加する。荷重 $P_{i}$ の作用点の $P_{i}$ 方向変位 $u_{i}$ は、Castiglianoの定理を(4)式 に適用して、

$$
\begin{aligned}
u_{i} & =\frac{\partial \bar{W}(P, A)}{\partial P_{i}} \\
& =\frac{\partial \bar{W}_{0}}{\partial P_{i}}+\frac{\partial \Delta \bar{W}(P, A)}{\partial P_{i}} \\
& =u_{i 0}+\int_{0}^{A} \frac{\partial G(P, A)}{\partial P_{i}} d A
\end{aligned}
$$

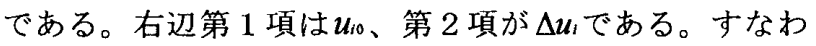
ち、クラックの存在による変位の増加分は、

$$
\Delta u_{i}=\frac{\partial \Delta \bar{W}(P, A)}{\partial P_{i}}=\int_{0}^{A} \frac{\partial G(P, A)}{\partial P_{i}} d A
$$

で与えられる。クラック先端の応力抎大係数が、外力お よびクラック寸法の関数として知られているとき便利な ように、(6)式を応力拡大係数を用いて書き直す。エネル ギ一解放率と応力拡大係数 $\left(K_{I}, K_{I I}, K_{I I}\right)$ との間には、周 知の次の関係式が存在する(7)。

$$
\begin{aligned}
& G=\frac{1}{E^{\prime}}\left(K_{\mathrm{I}}^{2}+K_{\mathrm{II}}^{2}\right)+\frac{1}{2 \mathrm{G}} K_{\mathrm{III}}^{2} \\
& \text { ただし、 } E^{\prime}= \begin{cases}E & \text { (plane stress) } \\
E /\left(1-v^{2}\right) & \text { (plane strain) }\end{cases}
\end{aligned}
$$

ここで、 $\mathrm{G}$ はせん断弾性係数、Eはたて弾性係数、vは ポアソン比である。

応力扡大係数の引数を荷重 $P_{1}, P_{2}, \cdots \cdots$ とクラック面 積 $A$ と考えて、(7)式の荷重 $P_{i}$ に関する偏微分を、(6)式に 代入すると、

$$
\begin{array}{r}
\Delta u_{i}=\int_{0}^{A}\left\{\frac{2}{E^{\prime}}\left(K_{\mathrm{I}} \frac{\partial K_{\mathrm{I}}}{\partial P_{i}}+K_{\mathrm{II}} \frac{\partial K_{\mathrm{II}}}{\partial P_{i}}\right)\right. \\
\left.+\frac{1}{\mathrm{G}} K_{\mathrm{III}} \frac{\partial K_{\mathrm{III}}}{\partial P_{i}}\right\} d A
\end{array}
$$

が得られる。 
(1) 円周ノッチを有する丸棒の引張による変形

半径 $R 、$ ノッ部の最小断面の半径が $b$ の丸棒が引張 力 $P$ を受けるときの変形を考える（図－1の (1)）。変形 $u$ をノッチが存在しない場合の変位 $u_{0}$ とノッチの存在 による増加分 $\Delta u$ に分けて考えると、

$$
u=u_{0}+\Delta u
$$

である。 $u_{0}$ は簡単に、ゲージ長さを $L$ として

$$
u_{0}=\frac{P L}{\pi R^{2} E}
$$

より求められる。ノッチによる増加分は、(8)式より

$$
\Delta u=\int_{0}^{A} \frac{2}{E^{\prime}} K_{\mathrm{I}} \frac{\partial K_{\mathrm{I}}}{\partial P_{i}} d A
$$

から計算できる。ここで $K_{\mathrm{I}}$ は円周ノッチを有する丸棒 の引張に対する応力拡大係数であり、次の近似式が得ら れている(9)。

$$
\begin{aligned}
& K_{\mathrm{I}}=\frac{P}{\pi b^{2}} \sqrt{\pi b} F(b / R) \quad ; \quad b / R=\xi \quad \text { とおくと } \\
& F(\xi) \approx \frac{1}{2}\left(1+\frac{1}{2} \xi+\frac{3}{8} \xi^{2}-0.363 \xi^{3}+0.731 \xi^{4}\right) \sqrt{1-\xi}
\end{aligned}
$$

また、軸対称問題のため、必然的に平面ひずみ状態とな ることを考慮すると(11)式より

$$
\Delta u=\frac{4\left(1-v^{2}\right) P}{E R^{2}}-\int_{b}^{R}\left(\frac{R}{b}\right)^{2}\{F(b / R)\}^{2} d b
$$

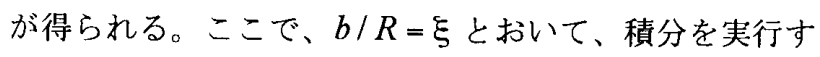
ると、

$$
\begin{aligned}
\Delta u= & \frac{\left(1-v^{2}\right) P}{E R} \int_{\xi}^{1} \frac{1}{\xi^{2}}\left(1+\frac{1}{2} \xi+\frac{3}{8} \xi^{2}\right. \\
& \left.-0.363 \xi^{3}+0.731 \xi^{4}\right)^{2}(1-\xi) d \xi \\
= & \frac{\left(1-v^{2}\right) P}{E R}\left(-1.413+\frac{1}{\xi}+0.676 \xi^{2}\right. \\
& -0.530 \xi^{3}+0.195 \xi^{4}-0.044 \xi^{5} \\
& \left.+0.202 \xi^{6}-0.152 \xi^{7}+0.067 \xi^{8}\right)
\end{aligned}
$$

となり、ノッチの存在による変位の増加分 $\Delta u$ が求められ る。本実験で用いる試験体の形状および材料定数を代入 して計算すると、弾性変形は $1 / 100 \mathrm{~mm}$ 以下と非常に小さ
く、その変位测定には、高感度の変位計が必要となるこ とがわかる。

(2) 円周ノッチを有する丸棒の曲げによる回転角

次に、曲げモーメントMを受けるときの回転角 $\theta$ を考 える（図ー1の (2)）。引張と同様、曲げモーメントによ る回転角 $\theta$ をノッチが存在しない場合の回転角とノッチ の存在による増加分に分けて考えるが、本試験体寸法の 場合、ノッチによる增加分の方が支配的であるため、そ れぞれの記号を $\theta_{\text {no crack }}$ と $\theta_{\text {crack }}$ とすると、

$$
\theta=\theta_{\text {no crack }}+\theta_{\text {crack }}
$$

である。 $\theta_{\text {no crack }}$ は簡単に、試験体長さを $l$ とすると

$$
\theta_{\text {no crack }}=\frac{M l}{2 E I}=\frac{2 M l}{\pi E R^{4}}
$$

となる。また、円周ノッチを有する丸棒の曲げに対する 応力搪大係数は

$$
\begin{aligned}
& K_{I}=\frac{4 M}{\pi b^{3}} \sqrt{\pi b} F(b / R) ; \quad b / R=\xi \quad \text { とおくと、 } \\
& F(\xi) \approx \frac{3}{8}\left(1+\frac{1}{2} \xi+\frac{3}{8} \xi^{2}+\frac{5}{16} \xi^{3}+\frac{35}{128} \xi^{4}+0.531 \xi^{5}\right) \sqrt{1-\xi}
\end{aligned}
$$

で近似できる(9)。したがって、 $\theta_{\text {crack }}$ は、

$$
\begin{aligned}
\theta_{\text {crack }} & =\int_{0}^{A} \frac{2}{E^{\prime}} K_{I} \frac{\partial K_{I}}{\partial M} d A \\
& =\frac{64\left(1-v^{2}\right)}{E R^{4}} M \int_{b}^{R}\left(\frac{R}{b}\right)^{4}\{F(b / R)\}^{2} d b
\end{aligned}
$$

となる。ここで、 $b / R=\xi$ の変数変換を行い、積分を実行 すると、
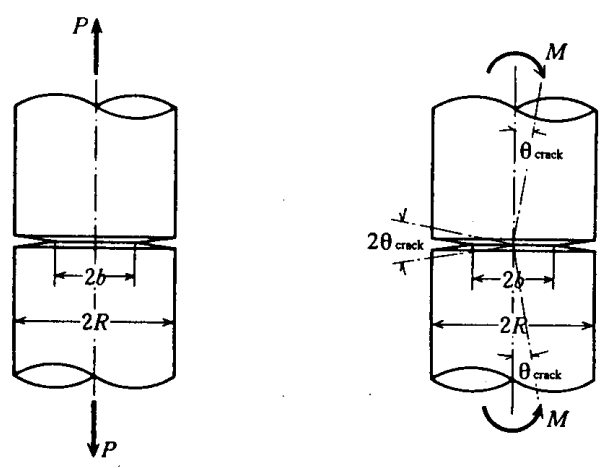
(1) 引張力
(2) 曲げモーメント

図-1 円周ノッチを有する丸棒の変形 


$$
\begin{aligned}
\theta_{\text {crack }}=\frac{9\left(1-v^{2}\right)}{E R^{3}} M \int_{\xi}^{1} \frac{1}{\xi^{4}}\left(1+\frac{1}{2} \xi+\frac{3}{8} \xi^{2}+\frac{5}{16} \xi^{3}\right. \\
\left.+\frac{35}{128} \xi^{4}+0.531 \xi^{5}\right)^{2}(1-\xi) d \xi \\
=\frac{9\left(1-v^{2}\right)}{E R^{3}} M\left(-0.448+\frac{1}{3 \xi^{3}}-0.285 \xi^{2}\right. \\
+0.245 \xi^{3}+0.066 \xi^{4}+0.033 \xi^{5} \\
\left.+0.019 \xi^{6}+0.001 \xi^{7}+0.035 \xi^{8}\right)
\end{aligned}
$$

が得られる。

\section{3. 実験方法}

直接引張試験に用いた試験体は、直径 $100 \mathrm{~mm}$ 、長さ 150 〜200mmのシリンダーである。最大荷重後の荷重一ク ラック開口変位関係を測定するために、試験体に円周切 り欠き(ノッチ) を導入し、クラック位置を規定してい

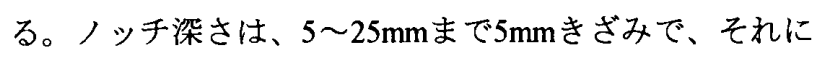
よって試験体名を表一1のように定める。ここで、球座の 有無とは、図ー2に示す実験装置のように、4本の鋼棒 によって構成された用な骨組の中に球座を組み込むと、 試験体の偏心を低減する効果はあるが、試験体にクラッ クが入ると同時に球座が回転し、クラックが急激に進展 するので最大荷重後の荷重一変位曲線を得ることができ ない。それ故、試験体の上下の球座を取り外して実験を 行ったが、偏心の影響を検討するために、N10-1および N20-1は、球座を取り付けて実験を行った試験体である。

試験体の調合を表一2に示す。普通ポルトランドセメ ントと天然骨材 (細骨材の最大寸法 $5 \mathrm{~mm}$, 粗骨材の最大 寸法 $20 \mathrm{~mm}$ ， 粗粒率=6.33）を使用した。打設後約 30 時間 で脱型し、材令28日まで標準水中養生を、その後試験日 （試験材令約 6 力月）まで $20^{\circ} \mathrm{C}$ の恒温室に放置した。 4 週圧縮強度は約 $400 \mathrm{~kg} / \mathrm{cm}^{2} 、 1$ 年圧縮強度は約 $480 \mathrm{~kg} / \mathrm{cm}^{2}$ であった。

ノッチは厚さ $1.2 \mathrm{~mm}$ のダイヤモンドブレードを、試験 体の表面位置から所定のノッチ梁さ位置まで、ダイヤル ゲージを用いて下げ、試験体を手動で回しながら導入し た。試験日の前日までに試験体の端面を仕上げ、エポキ シ系接着剂で鋼製の加圧盤に接着した。加圧盤を接着し た試験体は、図一2のように加力治具に取り付けられた。 加力はインストロン型25ton試験機を用いて、4 本の荷重 制御棒にあらかじめ引張力を導入して加力治具の遊びを 除去した後、一定の変位速度 $(0.005 \mathrm{~mm} / \mathrm{min}$. $)$ で載荷した。 荷重は $1 \mathrm{~kg}$ 感度のロードセルで、ノッチ部の開口変位は、 円周方向に等間隔な 3 力所に取り付けた $1 / 2500 \mathrm{~mm}$ 感度の クリップゲージで測定した（図ー3のCG1〜CG3）。この
3 カ所のクリップゲージの出力より、ノッチ断面の傾斜 が計算できる。さらに、クリップゲージの中間点におけ る変位をゲージ長さ $100 \mathrm{~mm}$ 、感度 $1 / 1100 \mathrm{~mm}$ のパイグージ で測定した（図ー3のPII〜PI3）。

$$
\text { 表 }-1 \text { 試験体名称 }
$$

\begin{tabular}{|c|c|c|}
\hline 試験体名 & ノッチ深さ & 球座の有無 \\
\hline $\mathrm{N} 05-2$ & $5 \mathrm{~mm}$ & 無 \\
\hline $\mathrm{N} 10-1$ & $10 \mathrm{~mm}$ & 有 \\
\hline $\mathrm{N} 10-2$ & $10 \mathrm{~mm}$ & 無 \\
\hline $\mathrm{N} 15-2$ & $15 \mathrm{~mm}$ & 無 \\
\hline $\mathrm{N} 20-1$ & $20 \mathrm{~mm}$ & 有 \\
\hline $\mathrm{N} 20-2$ & $20 \mathrm{~mm}$ & 無 \\
\hline $\mathrm{N} 25-2$ & $25 \mathrm{~mm}$ & 無 \\
\hline
\end{tabular}

表 -2 コンクリートの調合表

\begin{tabular}{|c|c|c|c|c|c|}
\hline \multirow{2}{*}{$\begin{array}{c}\text { 最大骨材 } \\
\text { 寸水セメント }\end{array} \quad$} & \multicolumn{4}{|c|}{ 単位重量 $\left(\mathrm{kg} / \mathrm{m}^{3}\right)$} \\
\cline { 3 - 6 } & 比 & 水 & セメント & 砂 & 砂 利 \\
\hline $20 \mathrm{~mm}$ & 0.55 & 194 & 353 & 689 & 1054 \\
\hline
\end{tabular}

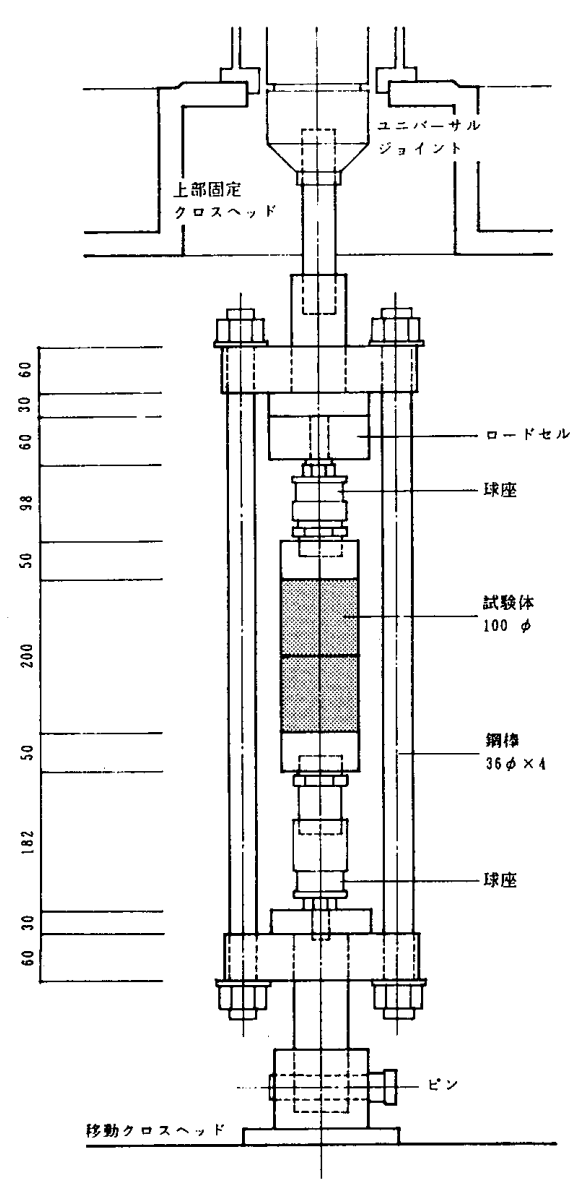

図-2 載荷装置 


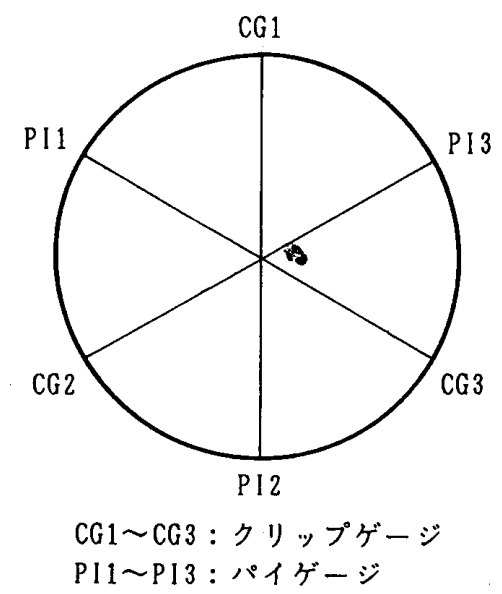

図-3 変位測定位置および変位記号

\section{4. 実験結果および考察}

表ー 3 に実験より得られた最大荷重、最小断面に対す る引張強度および最大荷重時のノッチ部平均開口変位を 示す。

図-4〜図-7に荷重一変位曲線を示す。試験体の上下 に球座を用いた試験体 N10-1 およびN20-1 は、前章で述 べたように、最大荷重よりわずかに荷重が低下した時点 で急激なクラック伝播が起こり、その後の荷重一変位曲 線が得られていない。一方、球座を取り外したその他の 試験体では、最大荷重後のクラック伝播が、4本の荷重 制御棒により拘束されるため、最大荷重後も荷重一変位 曲線が得られている。クリップゲージによる開口変位の 平均曲線（実線）とパイゲージによる平均変位曲線（実 線）とを比較すると最大荷重後ほぼ同様な举動を示して いることがわかる。これは、Hillerborg $(10)$ が指摘してい るように、最大荷重付近で破壊進行領域 (本試験体の場 合ノッチ部）が形成されると、その後の変位增分は破壊 領域内（ノッチ部）で生じ、その他の領域では荷重の減 少に伴って、ひずみも弹性的に隇少するためである。

球座の有無による引張強度を比較すると、球座を取り 外した試験体（N10-2、N20-2）の引張強度は、球座を取 り付けた試験体（N10-1、N20-1）の引張強度よりかなり 低下している(ノッチ $10 \mathrm{~mm}$ 試験体で $31 \%$ 減、 $20 \mathrm{~mm}$ 試験 体で34\%减）。球座を取り外すことによって、両端が完 全拘束状態になると、負の曲げモーメントの影響で引張 強度は高くなるはずである。しかし逆に強度が減少して いることから、本実験で用いた試験装置は、Reinhardt(6) の試験機と同様、極めて微小な弾性変形による回転まで 拘束することが出来なかったと言える。引張強度の相違 は、後述するノッチ部の傾斜角の変化に起因していると 考えられる。さらに、2 章で述べた線形破壊力学に基づ いて計算した変位とパイグージによる平均変位を比較し て図-8に示す。計算值は最大応力度の $1 / 3$ に相当する応
力度に対する割線弾性係数を用いているので、実験值は 荷重の上昇に伴って計算値より変位が大きくなり、上に

表 -3 実験結果

\begin{tabular}{|l|c|c|c|}
\hline 試験体名 & 最大荷重 & 引張強度 & $\begin{array}{c}\text { 最大荷重 } \\
\text { 時のクラック } \\
\text { 開口変位 } \\
(\mu \mathrm{m})\end{array}$ \\
\hline $\mathrm{N} 05-2$ & 1265 & 19.9 & 7.8 \\
\hline $\mathrm{N} 10-1$ & 1945 & 38.7 & 7.2 \\
\hline $\mathrm{N} 10-2$ & 1345 & 26.7 & 11.7 \\
\hline $\mathrm{N} 15-2$ & 1173 & 30.5 & 12.4 \\
\hline $\mathrm{N} 20-1$ & 1160 & 41.0 & 13.4 \\
\hline $\mathrm{N} 20-2$ & 764 & 27.0 & 11.0 \\
\hline $\mathrm{N} 25-2$ & 473 & 24.1 & 9.7 \\
\hline
\end{tabular}
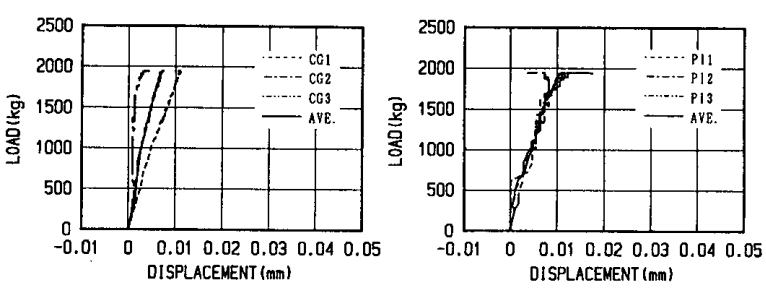

図-4 荷重－変位曲線：N10-1（球座有）
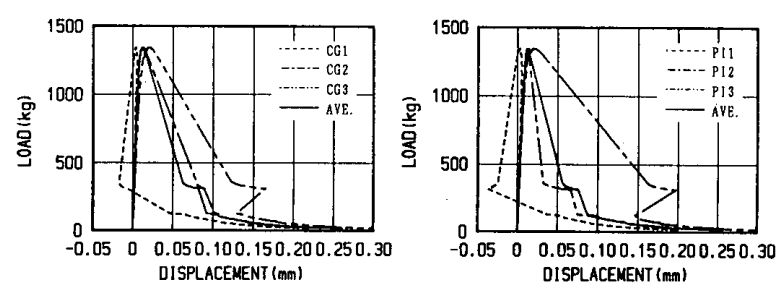

図-5 荷重一変位曲線： N10-2（球座無）
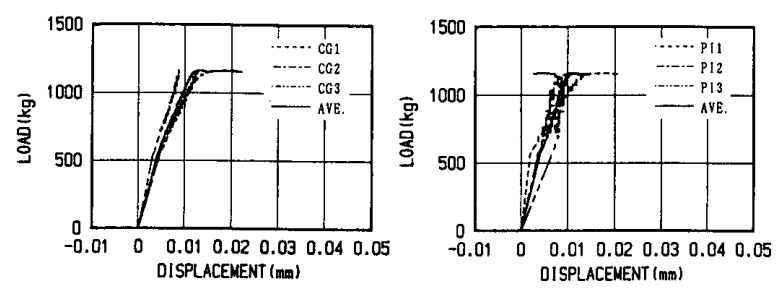

図-6 荷重－変位曲線： N20-1（球座有）
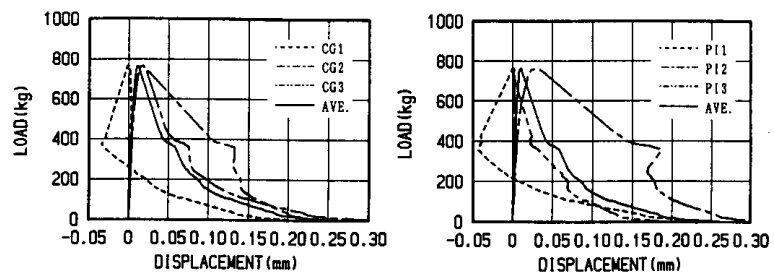

図-7 荷重一変位曲線： N20-2（球座無） 


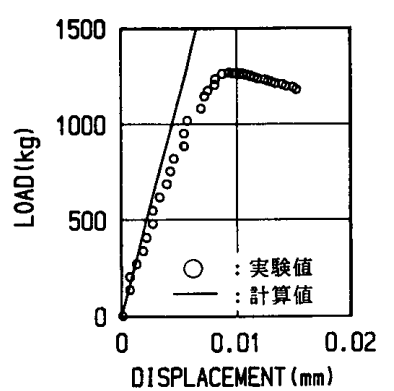

(1) N05-2

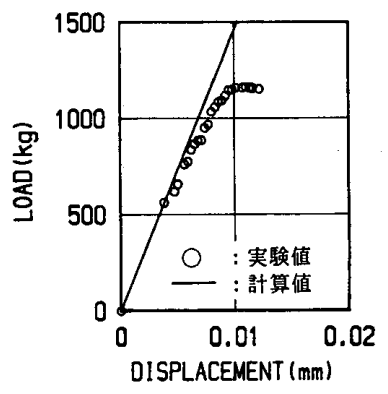

(5) N20-1:球座有

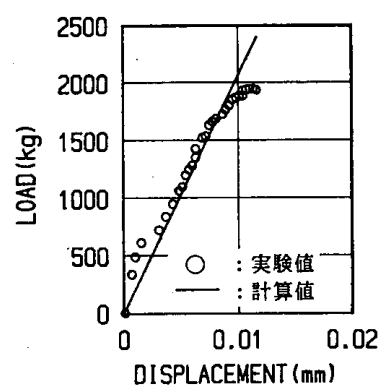

(2) N10-1: 球座有

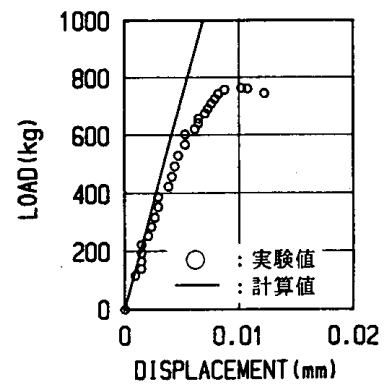

(6) $\mathrm{N} 20-2$

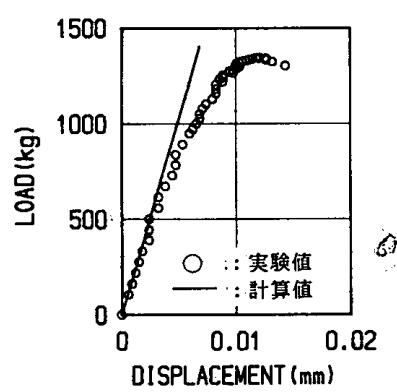

(3) $\mathrm{N} 10-2$

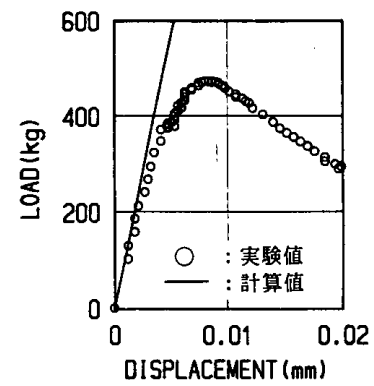

(7) $\mathrm{N} 25-2$

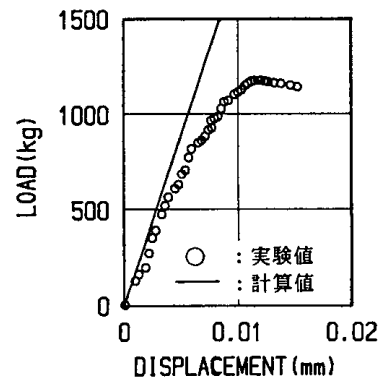

(4) $\mathrm{N} 15-2$

図-8 実験值（パイグージによる平均変位）と線形破壊力学による計算値の比較

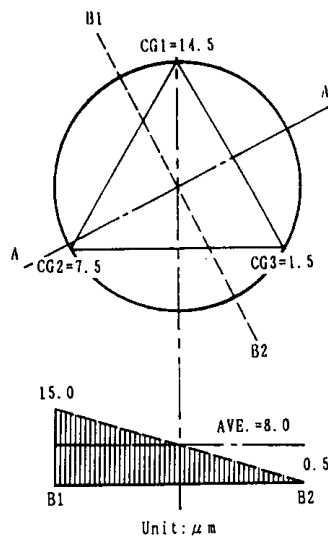

NOS-2 (Max. Load $=1265 \mathrm{~kg}$ )

(1) N05-2

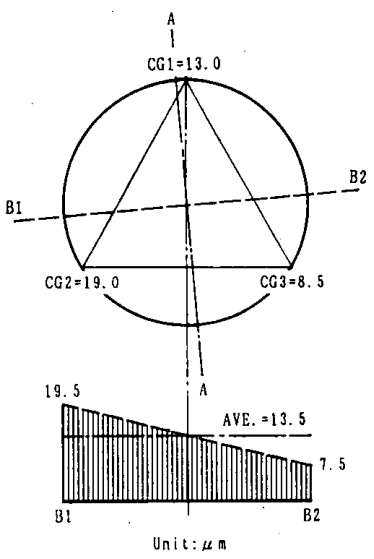

$N 20-1$ (Max. L Load $\left.=1160 \mathrm{~kg}_{\mathrm{B}}\right)$

(5) N20-1: 球座有

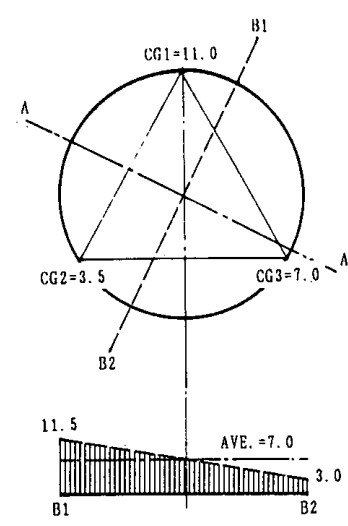

Unit: $\mu$ m

N10-1 (Max. Load $=1945 \mathrm{~kg})$

(2) N10-1: 球座有

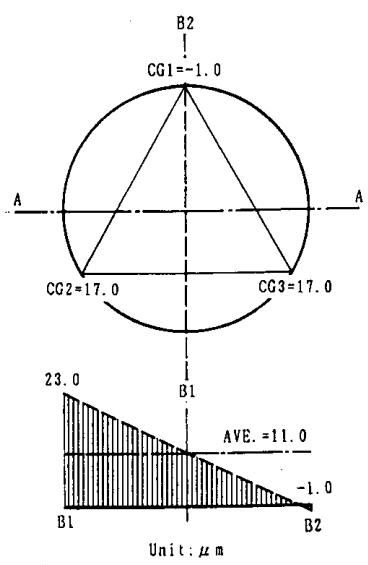

N20-2 (Max. L.oad $=764 \mathrm{~kg}$ )

(6) $\mathrm{N} 20-2$

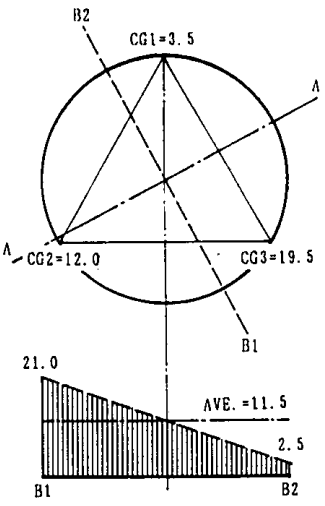

Unit: $\mu$ ๓

N10-2 (Max. Load $=1345 \mathrm{~kg})$

(3) $\mathrm{N} 10-2$

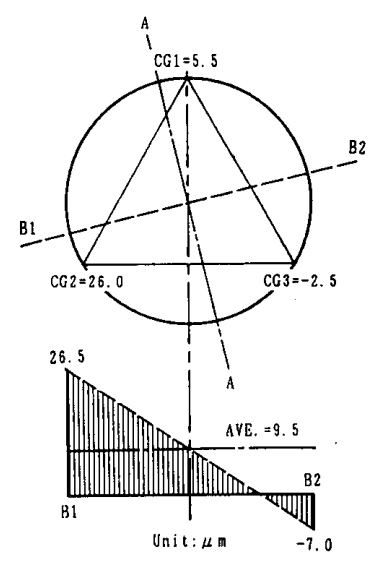

N25-2(Max. Load $=173 \mathrm{~kg})$

(7) $\mathrm{N} 25-2$

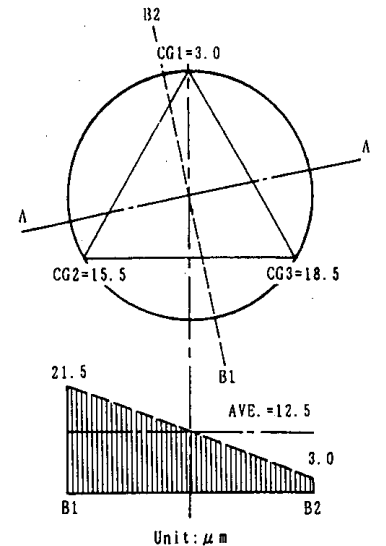

N15-2(Max. Load $=1173 \mathrm{~kg})$

(4) N15-2

図-9 最大荷重時におけるノッチ部断面の最大傾斜 
凸の曲線となる。球座を取り付けた試験体と取り外した 試験体を比べると、球座を取り外した試験体の方が、曲 げの影響により塑性域が広がり、荷重の上昇に伴って、 より大きな変位を生じている。図ー9に、最大荷重時に おけるノッチ断面部の最大傾斜を、3 個のクリップゲー ジより評価して示す。この図から明らかなように、球座 の無い試験体は、球座を有する試験体の 2 倍以上の傾斜 角となっており、試験体が完全弾性体であれば 2 倍以上 の曲げモーメントが生じたことになる。さらに試験体を 弾性体と見なせる最大荷重前におけるノッチ部断面の最 大傾斜の変遷を、ノッチ $10 \mathrm{~mm}$ の試験体について、図一 10、11に示す。球座を有するN10-1 試験体では最大荷重 の約 $40 \%$ で、最大荷重時の傾斜方向（図-10のB1-B2方 向）とほぼ同じ傾斜方向を示し、荷重の増加に伴って傾 斜角も增大する。しかし、荷重が最大荷重の約 $80 \%$ に達 すると、傾斜角の增大は見られなくなり、ほぼ同一傾斜 角で引張変形が進行している。一方、球座の無いN10-2 試験体では、載荷初期の段階から、最大荷重時の傾斜方 向とほぼ同じ傾斜方向を示す。最大荷重の $40 \%$ 位迄は、 その傾斜角の增大は少ないが、70\%を越えると、急激に

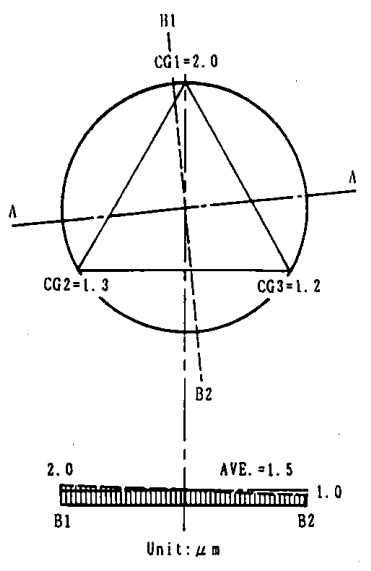

N10-1 (Load $=410 \mathrm{~kg})$

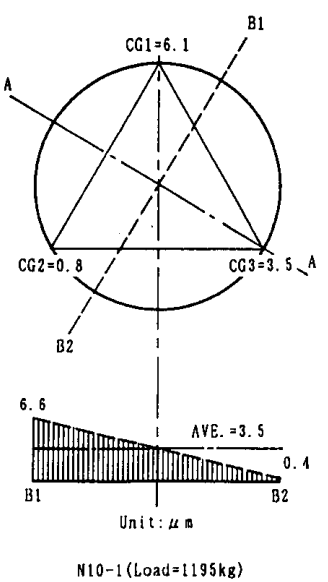

図-10 最大荷重前におけるノッチ部断面の傾斜の変化 : N10-1 (球座有)
增大し始める。ノッチ $20 \mathrm{~mm}$ 試験体についても、球座の無 いN20-2 試験体は、最大荷重に近づくと急激に傾斜角が 増大した。ここで、球座の有無によるノッチ部の傾斜角 の変化に注目して、引張強度の相違を推論すると次のよ うになる。球座を取り付けた試験体は、偏心距離を抑え る機能があり、最大耐力までノッチ部の傾斜角は比較的 小さい。一方、球座を取り外すと、この偏心を調整する 機能がなくなり、傾斜方向は初期段階から固定され、最 大耐力に近づくと急激に傾斜角（偏心曲げモーメント） が増加し、球座を取り付けた場合より引張強度が低下す る。

次に、図ー10、11のノッチ部断面の傾斜角から、2 章 の線形破壊力学に基づく方法によって、試験体に作用す る曲げモーメントを算定し、表ー4に示す。同表には曲 げモーメントの他に、偏心距㕍、曲げ応力および全応力 度 (引張応力度+曲げ応力度) も示している。最大荷重 時の全応力度より引張強度を推定すると、 $50 \sim 60 \mathrm{~kg} / \mathrm{cm}^{2}$ となるが最大荷重時まで線形破壊力学を適用した場合、 曲げモーメントを過大評価することになり、この強度も 過大評価となる。球座を有する試験体(N10-1、N20-1)の
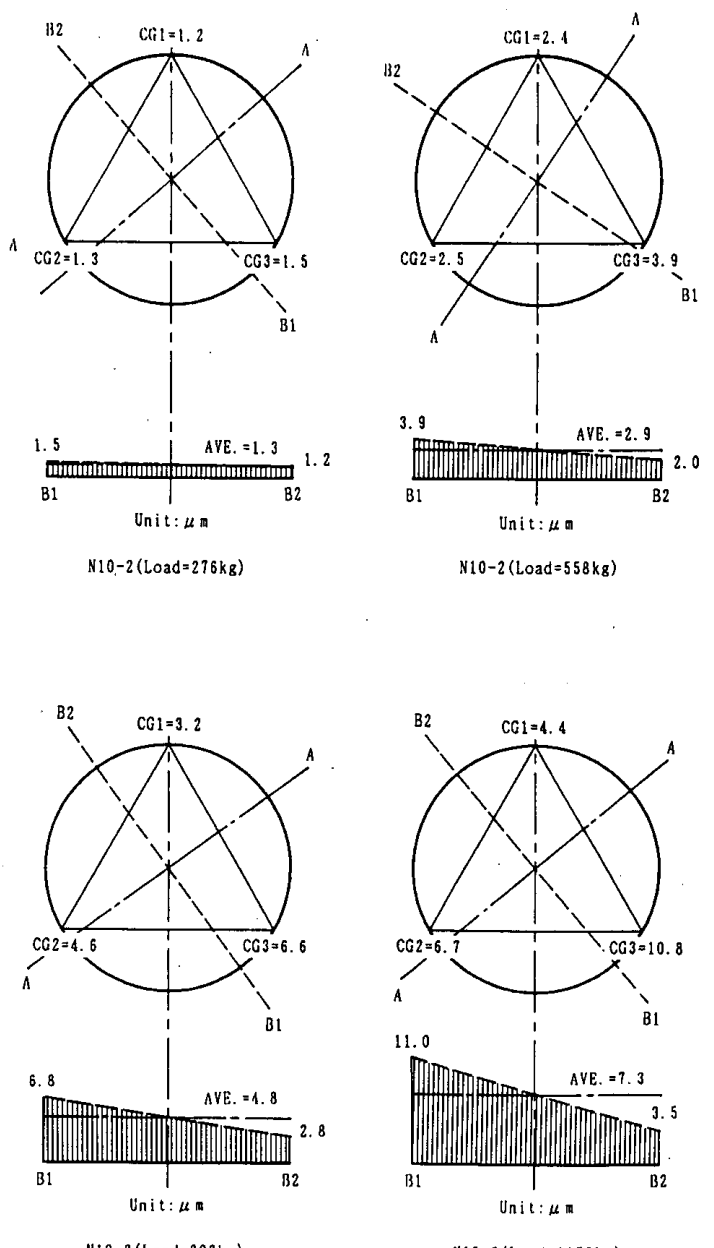

図ー11 最大荷重前におけるノッチ部断面の傾斜の変化 N10-2 (球座無) 
偏心距離仗、最大荷重まで、ごく限られた範囲内にある ので、実用上、これらの試験体の引張強度 $\left(40 \mathrm{~kg} / \mathrm{cm}^{2}\right.$ 程 度）を用いても差し支えないと思われる。

\section{表一4 線形破壊力学によって算定した曲げモーメント}

\begin{tabular}{|c|c|c|c|c|c|c|c|}
\hline 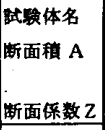 & $\begin{array}{l}\text { 荷 重 } \\
\mathrm{P} \\
(\mathrm{kg}) \\
\end{array}$ & $\left|\begin{array}{c}\text { 引层応力度 } \\
\sigma \mathrm{t} \\
\left(\mathrm{kg} / \mathrm{cm}^{2}\right)\end{array}\right|$ & $\left.\begin{array}{c}\left(\frac{s_{1}-B_{2}}{D}\right) / 2 \\
D\end{array}\right) / 2$ & 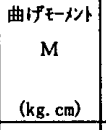 & $\begin{array}{c}\text { 偏心味踓 } \\
\mathrm{e}=\mathrm{M} / \mathrm{P} \\
\\
(\mathrm{mm})\end{array}$ & $\left|\begin{array}{c}\text { 曲げ応力席 } \\
\mathrm{oM} \\
\\
\left(\mathrm{kg} / \mathrm{cm}^{2}\right)\end{array}\right|$ & $\begin{array}{l}\text { 全応力度 } \\
\sigma \mathrm{t}+\sigma \mathrm{M} \\
\left(\mathrm{kg} / \mathrm{cm}^{2}\right) \\
\end{array}$ \\
\hline \multirow{5}{*}{$\begin{array}{l}N 10-1 \\
A=50.3 \mathrm{~cm}^{2} \\
Z=50.3 \mathrm{~cm}^{3}\end{array}$} & 410 & 8.2 & 0.50 & 110 & 2.7 & 2.2 & 10.4 \\
\hline & 835 & 16.6 & 1.85 & 407 & 4.9 & 8.1 & 24.7 \\
\hline & 1195 & 23.8 & 3. 10 & 681 & 5.7 & 13.5 & 37.3 \\
\hline & 1590 & 31.6 & 4. 35 & 956 & 6.0 & 19.0 & 50.6 \\
\hline & (1945) & $(38.7)$ & $(4.25)$ & (934) & (4.8) & (18.6) & (57.3) \\
\hline \multirow{5}{*}{$\begin{array}{l}N 10-2 \\
A=50.3 \mathrm{~cm}^{2} \\
Z=50.3 \mathrm{~cm}^{3}\end{array}$} & 276 & 5.5 & 0.15 & 33 & 1.2 & 0.7 & 6.2 \\
\hline & 558 & 11.1 & 0.95 & 209 & 3.7 & 4.2 & 15.3 \\
\hline & 892 & 17.7 & 2.00 & 440 & 4.9 & 8.7 & 26.4 \\
\hline & 1178 & 23.4 & 3.75 & 824 & 7.0 & 16.4 & 39.8 \\
\hline & $(1345)$ & (26.7) & $(9.25)$ & (2033) & (15. 1) & $(40.4)$ & $(67.1)$ \\
\hline \multirow{5}{*}{$\begin{array}{l}\mathrm{N} 20-1 \\
A=28.3 \mathrm{~cm}^{2} \\
Z=21.2 \mathrm{~cm}^{3}\end{array}$} & 617 & 21.8 & 1.05 & 43 & 0.7 & 2.0 & 23.8 \\
\hline & 800 & 28.3 & 1.40 & 57 & 0.7 & 2.7 & 31.0 \\
\hline & 1000 & 35.3 & 1.95 & 79 & 0.8 & 3.7 & 39.0 \\
\hline & 1100 & 38.9 & 2.70 & 109 & 1.0 & 5.1 & 44.0 \\
\hline & $(1160)$ & $(41.0)$ & $(6.00)$ & (243) & (2.1) & (11.5) & $(52.5)$ \\
\hline \multirow{5}{*}{$\begin{array}{l}N 20-2 \\
A=28.3 \mathrm{~cm}^{2} \\
Z=21.2 \mathrm{~cm}^{3}\end{array}$} & 194 & 6.9 & 0.75 & 30 & 1.5 & 1.4 & 8.3 \\
\hline & 389 & 13.7 & 1.30 & 53 & 1.4 & 2.5 & 16.2 \\
\hline & 568 & 20.1 & 2.60 & 105 & 1.8 & 5.0 & 25.1 \\
\hline & 659 & 23.3 & 4.85 & 196 & 3.0 & 9.2 & 32.5 \\
\hline & (764) & $(27.0)$ & $(12.00)$ & (486) & (6.4) & $(22.9)$ & $(49.9)$ \\
\hline
\end{tabular}

\section{5. まとめ}

コンクリートの直接引張試験結果が大きく変動する要 因として、曲げの影響を取り上げ、球座の有無による直 接引張試験を行い、線形破壊力学に基づいて、引張強度 に及ぼす曲げ変形の影響を考察した。これから以下の結 論を得た。

（1）球座の有無にかかわらず、試験体には曲げ変形が生 じる。これはコンクリート内の骨材粒子がランダム に分布しており、各断面における引張剛性の中心は、 断面の幾何学的中心とも、荷重の作用楾とも一致し ないためである。したがって、弾性範囲内から偏心 が存在し、最大荷重後、クラックは不均一に進行す るので、偏心も増大する。

（2）球座を有する試験体の偏心距離は、最大荷重まで増 加が少なく、曲げの影響は小さい。しかし、最大荷 重後、クラックが進行すると球座が回転するので安 定した荷重ークラック開口変位関係を得ることはで きない。
（3）最大荷重後も安定した荷重ークラック開口変位関係 を得るために、球座を取り外して行った試験では、 最大荷重に近づいていくと偏心距離が急增し、曲げ の影響が大きくなる。その結果、引張強度は、球座 を有する試験体と比較すると、30\%以上低下する。

（4）コンクリートの直接引張試験は、荷重ークラック開 口変位関係を決定する最も直接的な方法であるが、 コンクリート固有の不均質さに起因する曲げ変形を 避けることができないので、試験結果の評価は困難 である。

\section{参考文献}

1) B.P. Hughes and G.P. Chapman: The complete stress-strain curve for concrete in direct tension; Bulletin RILEM No.30 MARCH, pp.95-97, 1966

2) R.H. Evans and M.S. Marathe: Microcracking and Stressstrain Curves for Concrete in Tension, Materiaux et Constructions No.1, pp.61-64, 1968

3) V.S. Gopalaratnam and S.P. Shah: Softening Responce of Plain Concrete in Direct Tension; ACI Journal, Vol.82, No3, pp.310-323, 1985

4) Guo Zhen-hai and Zhang Xiu-qin: Investigation of Complete Stress-Deformation Curves for Concrete in Tension; ACI Material Journal, Vol.84, No.4, pp.278-285, 1987

5) H.W. Reinhardt: Fracture mechanics of an elastic softening materials like concrete; HERON, Vol.29, No.2, pp.2-42, 1984

6) H.A.W. Cornelissen, D.A. Hordijk and H.W. Reinhardt: Experiments and Theory for the Application of Fracture Mechanics to Normal and Lightweight Concrete; in Fracture Toughness and Fracture Energy of Concrete, ed. by F.H. Wittmann, Elsevier, pp.565-575, 1986

7) 岡村弘之：線形破壊力学入門 ; 培風館, p.226, 1976

8) A.A. Griffith: The Phenomena of Rupture and Flow in Solids; Philosophical Transactions of the Royal Society, Vol. A221, pp. 163-198, 1920

9) J.P. Benthem and W.T. Koiter: Asymptotic approximations to crack problems; in Mechanics of fracture 1 Methods of analysis and solutions of crack problems, ed. by G.C. Sih, Noordhoff, pp.131-178, 1973

10) A. Hillerborg: Analysis of One Single Crack; in Fracture Mechanics of Concrete, ed. by F.H. Wittmann, Elservier, pp.223-249, 1983

11）篠原保二、古村福次郎、安部武雄 : コンクリートの引張 強度に及ぼす曲げ変形の影響 ; 日本建築学会大会学術諢 “演梗概集A, pp.481-482, 1991

(1994 年 2 月 2 日原稿受理, 1994 年 8 月 5 日採用決定) 